UDC $\underline{69.059} ; 72.025 .5$

\title{
THE STUDY OF PROFITABILITY OF DWELLING RECONSTRUCTION OF FIRST MASS SERIES
}

\author{
Dubelt Tatiana $^{1 *}$ \\ ${ }^{1}$ Odessa State Academy of Building and Architecture https://orcid.org/0000-0003-2853-5704 \\ *Corresponding author E-mail: madam.tatiana3009@gmail.com
}

\begin{abstract}
The study of organizational and technological factors on dwelling reconstruction profitability of first mass series with the purpose to define the effective organizational solutions of reconstruction is described. The study is carried out on the basis of example of dwelling reconstruction of typical series 1-4382.5-7. The informative and graphical models of reconstruction are made. The factors having impact on reconstruction indexes are defined. The plan of numerical experiment considering simultaneous impact of the given factors on the profitability index of reconstruction is made. With the help of experimental and statistical modeling mathematical models of dependency of profitability on the factors in the form of charts are made. The charts analysis defined the areas of effective solutions by simultaneous impact of factors. By the results of studies the conclusions about the conditions of such dwellings reconstruction operations are made.
\end{abstract}

Key words: charts, the areas of effective solutions, models of reconstruction, experimental and statistical modeling, organizational and technological factors.

\section{ДОСЛІДЖЕННЯ ЗМІНИ РЕНТАБЕЛЬНОСТІ РЕКОНСТРУКЦІї ЖИТЛОВИХ БУДИНКІВ ПЕРШИХ МАСОВИХ СЕРІЙ}

\author{
Дубельт Т.М. ${ }^{1 *}$ \\ ${ }^{1}$ Одеська державна академія будівництва та архітектури \\ *Адреса для листування E-mail: madam.tatiana3009@gmail.com
}

\begin{abstract}
Описане дослідження впливу організаційно-технологічних факторів на рентабельність реконструкції житлових будинків перших масових серій, з метою визначення ефективних організаційних рішень реконструкції. В інформаційних джерелах відсутня інформація щодо методики дослідження реконструкції подібних об'єктів. А фактична реконструкція будинків носить епізодичний характер та не дає можливості визначити вплив факторів на показники реконструкції, тому що проходить при фіксованих значеннях факторів. Як наслідок - небажання інвесторів вкладати кошти в реконструкцію житлових будинків типових серій. Для вирішення поставленої проблеми були вибрані впливові фактори, визначений перелік робіт, побудовані та досліджені абстрактні моделі реконструкції. Дослідження проведені на прикладі реконструкції житлового будинку типової серії 1-4382.5-7. Побудовані інформаційні та графічні моделі реконструкції. Визначені фактори що впливають на показник реконструкції серед яких: кількість робочих годин на тиждень, ступінь суміщення робіт, необхідна частка заміни прорізів та комунікацій. Визначені рівні варіювання кожного з факторів: мінімальне, максимальне та середнє значення. Складено план чисельного експерименту що враховує одночасний вплив визначених факторів на показники реконструкції. Отримані основні показники реконструкції: тривалість, вартість та рентабельність робіт. За допомогою експериментально-статистичного моделювання побудовані математичні моделі залежності показника рентабельності від факторів у вигляді математичних формул та діаграм. Аналіз діаграм визначив зони ефективних рішень при одночасному впливі всіх факторів. За результатами досліджень зроблені висновки про умови проведення реконструкції подібних будинків.
\end{abstract}

Ключові слова: діаграми, зони ефективних рішень, моделі реконструкції, експериментально-статистичне моделювання, організаційно-технологічні фактори. 


\section{Introduction}

During 60-80 years of the XX century in the countries of the former USSR and Europe the dwellings mass building of first mass series has started. The USSR has been built in postwar period, thus the works were carried out under the conditions of strong economy of material costs. Dwellings were considered as lodging of 25-30 years of operation. [1]. The amount of such dwellings forms $25 \%$ of all housing facilities of Ukraine [2]. The level of comfortable living is very low, flats size length is small, a bathroom is combined with a toilet, inner walls have weak sound insulation. This type of buildings is characterized by great amount of heat loss, lack of elevator, balconies, rubbish chute and attic. The analysis of demolition of such buildings forms 30-40\%.[3]. Every third house needs urgent repairing or modernization in Ukraine. Considering the described difficulties reconstruction of such houses is possible and enables to prolong their service life till 50 years. Lack of such houses reconstruction capabilities and demolition analysis in modern literature; calculations of reconstruction additional financing lead to investors' unwillingness to put money into such projects. Study of abstract models of reconstruction with the help of computer programs enabled to obtain calculations and to trace the impact of organizational and technological factors on reconstruction indexes including profitability.

\section{Review of the research sources and publications}

As a rule, volumetric and planning solutions of such houses are described the native literary sources. According to them, the set of reconstruction measures to raise the living comfort level is proposed [4-6]. The description of implemented objects enabled to define the set of works that can be used for majority of series of such houses. In foreign literary sources there are examples of successful reconstruction [7-10], and the necessity of houses demolition of such series. On the basis of analyzed publications it can be concluded that the dwellings of first mass series can be divided into 2 groups: first group where reconstruction is proper, the second group where there are houses to be demolished.

\section{Definition of unsolved aspects of the problem}

The analysis of informative sources showed that lack of reconstruction methods impact description on technical and economical indexes does not enable to have an idea about the conditions of dwellings profitable reconstruction of first mass series. The amount of implemented objects in Ukraine is less than 20, thus it does not enable to make conclusions about factors influencing reconstruction indexes.

\section{Problem statement}

The study of simultaneous impact of factors by their different combination on reconstruction indexes enables to obtain maximum amount of the material for the study with minimum costs. The solution of the given task is implemented via making abstract models imitating reconstruction of the dwelling under different conditions and their study with usage of software. By the results of the study the areas of effective solutions of profitable reconstruction have been defined.

\section{Basic material and results}

The examples of carried out reconstruction showed that reconstruction is made by different conditions of works execution: under eviction or habitants' living in the house while doing the reconstruction. The conditions of works execution have impact on amount of working hours per a week. Two basic models have been made for the study considering these conditions.

The studies were conducted using mathematical theory of experiment planning, which is the basis of experimental and statistical modeling $[11,12]$. According to the classical theory of reduced experiment varying factors planning must be over the range according to classical $-1 ; 0 ;+1$. Every factor and the ranges of varying are presented below in details.

The first factor-amount of working hours per week $\left(X_{1}\right)$ depends on the amount of working hours per week and the amount of working hours per day [13].

Accepted amount of working hours per week is:

- by habitants' eviction while conducting reconstruction: 40, 80 and 112 hours.

- by habitants' living during reconstruction: 40, 48 and 60 hours.

The second factor - degree of works' overlapping $\left(X_{2}\right)$ presents ratio of reconstruction period duration to the total of works duration in each division (Formula 1) is characterized by coefficient of overlapping and is variable from $0.15,0.2$ and 0.25

$$
X_{2}=k_{c o m}=\frac{T_{c}}{\Sigma_{1}^{N} \cdot \Sigma_{1}^{n} t_{i}},
$$

where:

$T_{c}$ - duration of the reconstruction period, days;

$N$ - amount of processes;

$n$ - amount of divisions by flow organization;

$t_{i}$ - duration of $i$-th flow, days.

The third factor - necessary part of slots displacement $\left(X_{3}\right)$ was defined on the basis of visual inspection of such houses and forms 20,50 and 80\% from total amount of slots.

The fourth factor - necessary part of communications replacement $\left(X_{4}\right)$ depends on the quantity of porches and risers in analyzed house and it is variable from: $8.33,50.0$ and $91.66 \%$ from total amount. The range of variation of two last factors is connected with independent replacement of separate elements by habitants during house operation.

Reconstruction profitability presents relation of profit to reconstruction cost. For its determination it is needed to obtain works duration, to calculate the cost and profit from the dwelling reconstruction.

The studies were carried out by the example of dwelling reconstruction in one of the spread series $1-438_{2.5}-7$. For the reconstruction laboriousness there is formed informative model in the form of estimate in the program ABK-5 (3.2.2) at prices of 2016 year.

With the help of program Microsoft Project on the basis of works laboriousness it is made linear charts by simultaneous impact of all factors according to two 
plans of numerical experiment. The first plan considered the condition of habitants' eviction while making operations (Table 1-2). The second plan was elaborated under the condition of habitants' living during the reconstruction.

The cost of reconstruction considered the costs of habitants' eviction during operations by formula

$$
C=C_{\text {r.m.w. }}+C_{f l . b .}+C_{\text {t.l. }},
$$

where:

$C$ - cost of object's reconstruction, hryvnas.;

$C_{r . m . w .}-$ cost of repair and construction works by estimation, hryvnas;

$C_{f l . b .}$ - costs on flat's buying on the ground floor connected with flats' alterations for additions to elevator shaft, hryvnas;

$C_{t . l .}$ - costs on payment of temporary lodging to habitants during reconstruction

$$
C_{\text {t.l. }}=C_{m . c .} \times T_{r},
$$

where:

$C_{m . c .}$ - monthly costs on payment of temporary lodging to habitants during reconstruction, hryvnas; $T_{r}-$ reconstruction duration, months.

Reconstruction profitability is in inverse proportion to works cost. Calculations were made by formula

$$
P=\frac{P r}{C} \times 100 \%,
$$

where:

$P$ - profitability, \%;

$\mathrm{Pr}$ - profit of reconstruction object, thousand hryvnas;

$C$ - cost of object reconstruction, thousand hryvnas;

Reconstruction profit was calculated by formula

$$
\operatorname{Pr}=C_{p} \times C,
$$

where:

$P r$ - profit of object's reconstructioni, hryvnas.;

$C_{p}$ - profit from new flats' sale on the ground, fifth and sixth floors after reconstruction.
On the ground floor the flats are repurchased and replanned because of additions to elevator. After reconstruction termination built-on flats on the fifth and sixth floors and altered flats of the ground floor are put up for sale.

Factors impact on indexes is ambiguous: in case of eviction the first two factors have an impact on works duration (Table 1), and all the fourth only on cost and profitability (Table 2). By habitants' living in the house the factors impact is pairwise: the first two factors have an impact on reconstruction duration (Table 3), and the third and the fourth on cost and profitability (Table 4). On the basis of calculations, it is obtained numerical indexes of duration, cost and profitability of dwelling reconstruction (Table 1-4).

To define the factors impact on dwellings reconstruction profitability of first mass series it is made mathematical models with the help of program COMPEX. The description of dependencies of factors impact on profitability is presented in the form of analytical formula and charts.

Factors impact on profitability by habitants' eviction during reconstruction is described by formula

$$
\begin{aligned}
& Y_{1}=P=7.531+10.402 X_{1}-3.98 X_{1}^{2}+ \\
& +1.58 X_{1} X_{2}-0.44 X_{1} X_{3}-0.064 X_{1} X_{4}- \\
& -5.108 X_{2}-0.904 X_{2}^{2}+0,241 X_{2} X_{3}+ \\
& +0.031 X_{2} X_{4}-2.28 X_{3}+0.144 X_{3}^{2}+ \\
& +0.015 X_{3} X_{4}-0.33 X_{4}+0.074 X_{4}^{2} .
\end{aligned}
$$

The analysis of the given mathematical dependency is shown that factor $X_{1}$ has the most sufficient impact on dwelling reconstruction profitability (amount of working hours per week). Positive mark of the coefficient $\mathrm{X} 1$ indicates that the change of this factor is in direct ratio to profitability change $\left(Y_{3}\right)$.

Table 1 - Plan of experiment and impact of varying factors $X_{1}$ and $X_{\mathbf{2}}$ on the index of duration of the dwelling reconstruction duration $\left(Y_{1}\right)$, condition of reconstruction - habitants' eviction during operations

\begin{tabular}{|c|c|c|c|c|c|}
\hline \multirow{2}{*}{$\begin{array}{c}\text { № of } \\
\text { point }\end{array}$} & \multicolumn{2}{|c|}{ Coded factors } & \multicolumn{2}{c|}{ Full-scale factors } & Indexes \\
\cline { 2 - 6 } & $\begin{array}{c}X_{1} \text { - amount of } \\
\text { working hours per } \\
\text { week }\end{array}$ & $\begin{array}{c}X_{2}-\text { coefficient of } \\
\text { works' overlap- } \\
\text { ping }\end{array}$ & $\begin{array}{c}X_{1} \text {-amount of } \\
\text { working hours per } \\
\text { week (hour) }\end{array}$ & $\begin{array}{c}X_{2} \text { - coefficient of } \\
\text { works' overlap- } \\
\text { ping }\end{array}$ & $\begin{array}{c}Y_{1}-\text { reconstruc- } \\
\text { tion duration, } \\
\text { (days) }\end{array}$ \\
\hline 1 & 2 & 3 & 4 & 5 & 6 \\
\hline 1 & -1 & -1 & 40 & 0,15 & 484 \\
\hline 2 & -1 & 0 & 40 & 0,2 & 670 \\
\hline 3 & -1 & 1 & 40 & 0,25 & 807 \\
\hline 4 & 0.11 & -1 & 80 & 0,15 & 243 \\
\hline 5 & 0.11 & 0 & 80 & 0,2 & 335 \\
\hline 6 & 0.11 & 1 & 80 & 0,25 & 404 \\
\hline 7 & 1 & -1 & 112 & 0,15 & 173 \\
\hline 8 & 1 & 0 & 112 & 0,2 & 239 \\
\hline 9 & 1 & 1 & 112 & 0,25 & 288 \\
\hline
\end{tabular}


Table 2 - Plan of experiment and impact of varying factors $\left(X_{1}, X_{2}, X_{3}\right.$ and $\left.X_{4}\right)$ on the index of study reconstruction cost $\left(Y_{2}\right)$ and profitability $\left(Y_{3}\right)$, condition of reconstruction - habitants' eviction during operations

\begin{tabular}{|c|c|c|c|c|c|c|c|c|c|c|}
\hline \multirow{2}{*}{$\begin{array}{l}\text { № of } \\
\text { point }\end{array}$} & \multicolumn{4}{|c|}{ Coded factors } & \multicolumn{4}{|c|}{ Full-scale factors } & \multicolumn{2}{|c|}{ Indexes } \\
\hline & 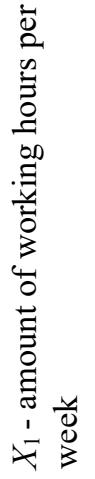 & 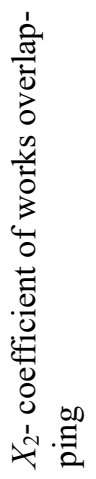 & 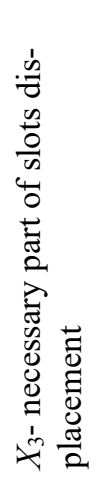 & 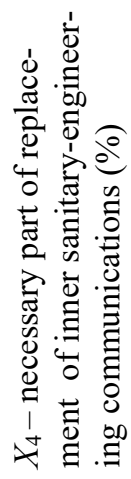 & 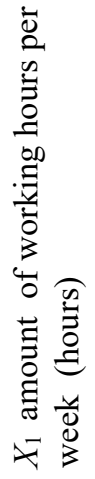 & 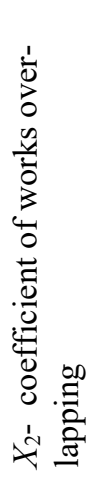 & 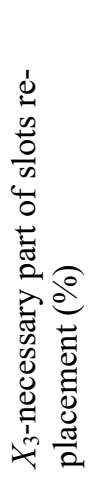 & 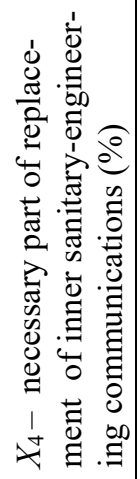 & 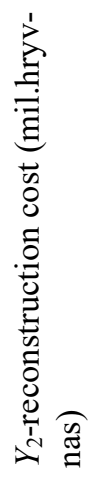 & 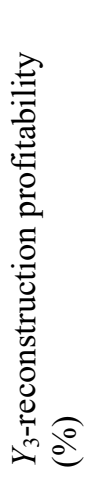 \\
\hline 1 & 2 & 3 & 4 & 5 & 6 & 7 & 8 & 9 & 10 & 11 \\
\hline 1 & 1 & 1 & 1 & 1 & 112 & 0.25 & 80 & 91.66 & 25.17 & 8.56 \\
\hline 2 & 1 & 1 & 1 & -1 & 112 & 0.25 & 80 & 8.33 & 25.0 & 9.26 \\
\hline 3 & 1 & 1 & -1 & 1 & 112 & 0.25 & 20 & 91.66 & 24.05 & 13.6 \\
\hline 4 & 1 & 1 & -1 & -1 & 112 & 0.25 & 20 & 8.33 & 23.89 & 14.37 \\
\hline 5 & 1 & -1 & 1 & 1 & 112 & 0.15 & 80 & 91.66 & 23.69 & 15.34 \\
\hline 6 & 1 & -1 & 1 & -1 & 112 & 0.15 & 80 & 8.33 & 23.52 & 16.13 \\
\hline 7 & 1 & -1 & -1 & 1 & 112 & 0.15 & 20 & 91.66 & 22.57 & 21.05 \\
\hline 8 & 1 & -1 & -1 & -1 & 112 & 0.15 & 20 & 8.33 & 22.41 & 21.93 \\
\hline 9 & -1 & 1 & 1 & 1 & 40 & 0.25 & 80 & 91.66 & 31.84 & -14.21 \\
\hline 10 & -1 & 1 & 1 & -1 & 40 & 0.25 & 80 & 8.33 & 31.68 & -13.77 \\
\hline 11 & -1 & 1 & -1 & 1 & 40 & 0.25 & 20 & 91.66 & 30.72 & -11.08 \\
\hline 12 & -1 & 1 & -1 & -1 & 40 & 0.25 & 20 & 8.33 & 30.56 & -10.61 \\
\hline 13 & -1 & -1 & 1 & 1 & 40 & 0.15 & 80 & 91.66 & 27.69 & -1.33 \\
\hline 14 & -1 & -1 & 1 & -1 & 40 & 0.15 & 80 & 8.33 & 27.52 & -0.75 \\
\hline 15 & -1 & -1 & -1 & 1 & 40 & 0.15 & 20 & 91.66 & 26.57 & 2.82 \\
\hline 16 & -1 & -1 & -1 & -1 & 40 & 0.15 & 20 & 8.33 & 26.41 & 3.45 \\
\hline 17 & -1 & 0 & 0 & 0 & 40 & 0.20 & 50 & 50 & 29.44 & -7.22 \\
\hline 18 & 0,11 & 1 & 0 & 0 & 80 & 0.25 & 50 & 50 & 26.02 & 4.98 \\
\hline 19 & 0,11 & -1 & 0 & 0 & 80 & 0.15 & 50 & 50 & 23.95 & 14.06 \\
\hline 20 & 0,11 & 0 & 1 & 0 & 80 & 0.20 & 80 & 50 & 25.69 & 6.34 \\
\hline 21 & 0,11 & 0 & 0 & 1 & 80 & 0.20 & 50 & 91.66 & 25.22 & 8.34 \\
\hline 22 & 0,11 & 0 & -1 & 0 & 80 & 0.20 & 20 & 50 & 24.57 & 11.18 \\
\hline 23 & 0,11 & 0 & 0 & -1 & 80 & 0.20 & 50 & 8.33 & 25.05 & 9.04 \\
\hline 24 & 0,11 & 0 & 0 & 0 & 80 & 0.20 & 50 & 50 & 25.14 & 8.69 \\
\hline 25 & 1 & 1 & 1 & 1 & 112 & 0.25 & 80 & 91.66 & 25.17 & 8.56 \\
\hline
\end{tabular}

Factor $X_{2}$ has impact half as large (coefficient of works overlapping), and the factor $X_{3}$ has impact five times less (necessary part of slots replacement). The impact of factor $X_{4}$ (necessary part of communications replacement) is insignificant. Negative marks of coefficients of factors $X_{2}, X_{3}, X_{4}$ show that their impact is in inverse ratio to profitability raise $\left(Y_{3}\right)$.

Impact of all 4 factors $X_{1}$ (amount of working hours per week), $X_{2}$ (coefficient of works' overlapping), $X_{3}$ (necessary part of slots' replacement ) and $X_{4}$ (necessary part of communications replacement ) on reconstruction profitability $\left(Y_{3}\right)$ by their different combination is presented in the chart «square by square " (fig. 1). To make the chart, it is made 9 two-factor charts (impact of factors $X_{1}$ and $X_{2}$ ), which are situated on the basic square. The basic square considers the impact of factors $X_{3}$ and $X_{4}$. On the chart the interval of reconstruction profitability change is depicted by contour lines with pace 5\%. 
Table 3 - Plan of experiment and impact of varying factors $X_{1}$ and $X_{2}$ on the index of the dwelling reconstruction $\left(Y_{1}\right)$, condition of reconstruction - habitants' eviction during operations

\begin{tabular}{|c|c|c|c|c|c|}
\hline \multirow{2}{*}{$\begin{array}{c}\text { № of } \\
\text { point }\end{array}$} & \multicolumn{2}{|c|}{ Coded factors } & \multicolumn{2}{c|}{ Full-scale factors } & Indexes \\
\cline { 2 - 6 } & $\begin{array}{c}X_{1}-\text { amount of } \\
\text { working hours per } \\
\text { week }\end{array}$ & $\begin{array}{c}X_{2}-\text { coefficient of } \\
\text { works' overlap- } \\
\text { ping }\end{array}$ & $\begin{array}{c}X_{1}-\text { amount of } \\
\text { working hours per } \\
\text { week } \\
\text { (hour) }\end{array}$ & $\begin{array}{c}X_{2}-\text { coefficient of } \\
\text { works' overlap- } \\
\text { ping }\end{array}$ & $\begin{array}{c}Y_{1} \text {-reconstruc- } \\
\text { tion duration, } \\
\text { (days) }\end{array}$ \\
\hline 1 & 2 & 3 & 4 & 5 & 6 \\
\hline 1 & -1 & -1 & 40 & 0.15 & 483 \\
\hline 2 & -1 & 0 & 40 & 0.2 & 651 \\
\hline 3 & -1 & 1 & 40 & 0.25 & 821 \\
\hline 4 & $-0,2$ & -1 & 48 & 0.15 & 402 \\
\hline 5 & $-0,2$ & 0 & 48 & 0.2 & 542 \\
\hline 6 & $-0,2$ & 1 & 48 & 0.25 & 673 \\
\hline 7 & 1 & -1 & 60 & 0.15 & 322 \\
\hline 8 & 1 & 0 & 60 & 0.2 & 518 \\
\hline 9 & 1 & 1 & 60 & 0.25 & 547 \\
\hline
\end{tabular}

Table 4 - Plan of experiment and impact of varying factors $X_{3}$ and $X_{4}$ on the index of reconstruction cost $\left(Y_{2}\right)$ and profitability $\left(Y_{3}\right)$, condition of reconstruction - habitants' eviction during operations

\begin{tabular}{|c|c|c|c|c|c|c|}
\hline \multirow{2}{*}{$\begin{array}{l}\text { № of } \\
\text { point }\end{array}$} & \multicolumn{2}{|c|}{ Coded factors } & \multicolumn{2}{|c|}{ Full-scale factors } & \multicolumn{2}{|c|}{ Indexes } \\
\hline & 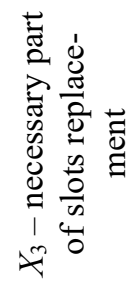 & 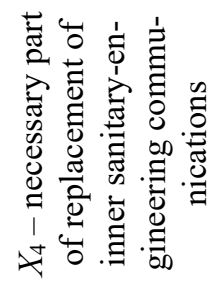 & 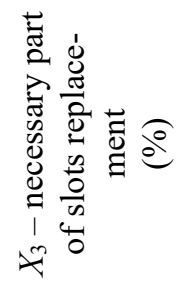 & 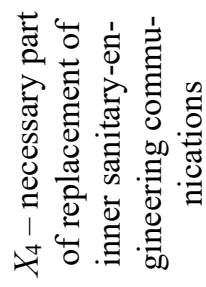 & 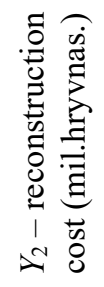 & 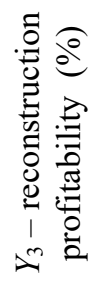 \\
\hline 1 & 2 & 3 & 4 & 5 & 6 & 7 \\
\hline 1 & -1 & -1 & 20 & 8.33 & 20.18 & 35.37 \\
\hline 2 & -1 & 0 & 20 & 50 & 20.26 & 34.83 \\
\hline 3 & -1 & 1 & 20 & 91.66 & 20.34 & 34.29 \\
\hline 4 & 0 & -1 & 50 & 8.33 & 20.74 & 31.69 \\
\hline 5 & 0 & 0 & 50 & 50 & 20.83 & 31.18 \\
\hline 6 & 0 & 1 & 50 & 91.66 & 20.91 & 30.67 \\
\hline 7 & 1 & -1 & 80 & 8.33 & 21.30 & 28.27 \\
\hline 8 & 1 & 0 & 80 & 50 & 21.38 & 27.78 \\
\hline 9 & 1 & 1 & 80 & 91.66 & 21.46 & 27.30 \\
\hline
\end{tabular}

The study of factors' impact: necessary part of slots replacement $\left(X_{3}\right)$ and necessary part of communications replacement $\left(X_{4}\right)$ on reconstruction profitability $\left(Y_{3}\right)$ without habitants' eviction is described by mathematical dependency by formula

$$
\begin{aligned}
& Y_{3}=P=31.179-3.523 X_{3}+0.127 X_{3}^{2}+ \\
& +0.028 X_{3} X_{4}-0.512 X_{4}+0.02 X_{4}^{2} .
\end{aligned}
$$

The analysis of the obtained analytical dependency illustrates that factor $X_{3}$ has the most substantial impact on reconstruction profitability of dwelling $\left(Y_{3}\right)$ gives factor $X_{3}$ (necessary part of slots replacement). Its impact is 7 times more than factor $X_{4}$ (necessary part of communications replacement). Negative marks of the coefficients $X_{3}$ i $X_{4}$ indicate that factors change is in inverse ratio to profitability change $\left(Y_{3}\right)$.

The impact of two factors $X_{3}$ and $X_{4}$ on indexes of reconstruction profitability $\left(Y_{3}\right)$ is depicted on 2-factor chart on Figure 2. 


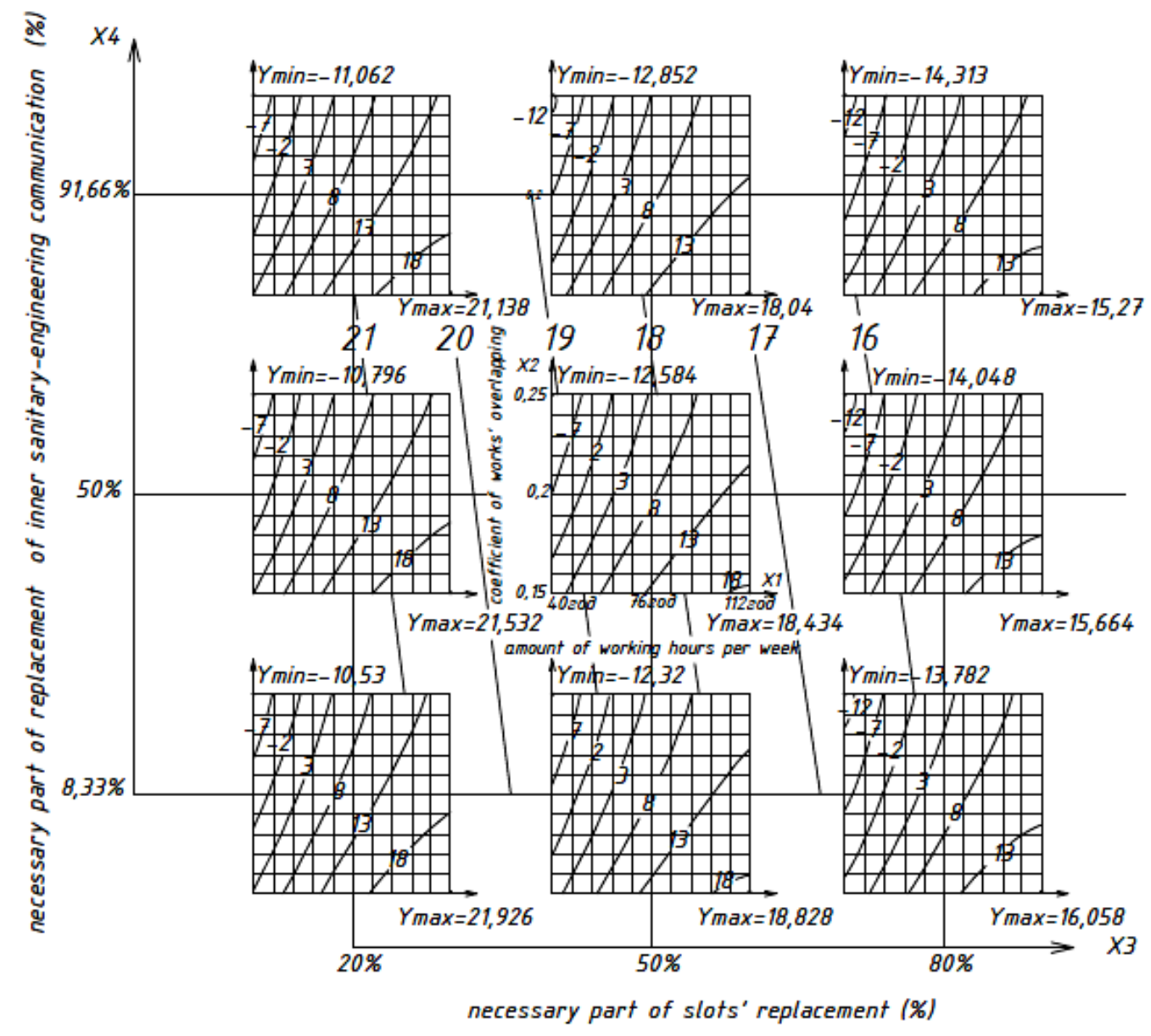

Figure 1 - Chart "square by square" presents impact of factors $\left(X_{1}, X_{2}, X_{3}, X_{4}\right)$ on reconstruction profitability $\left(Y_{3}\right)$ under the condition of habitants' eviction

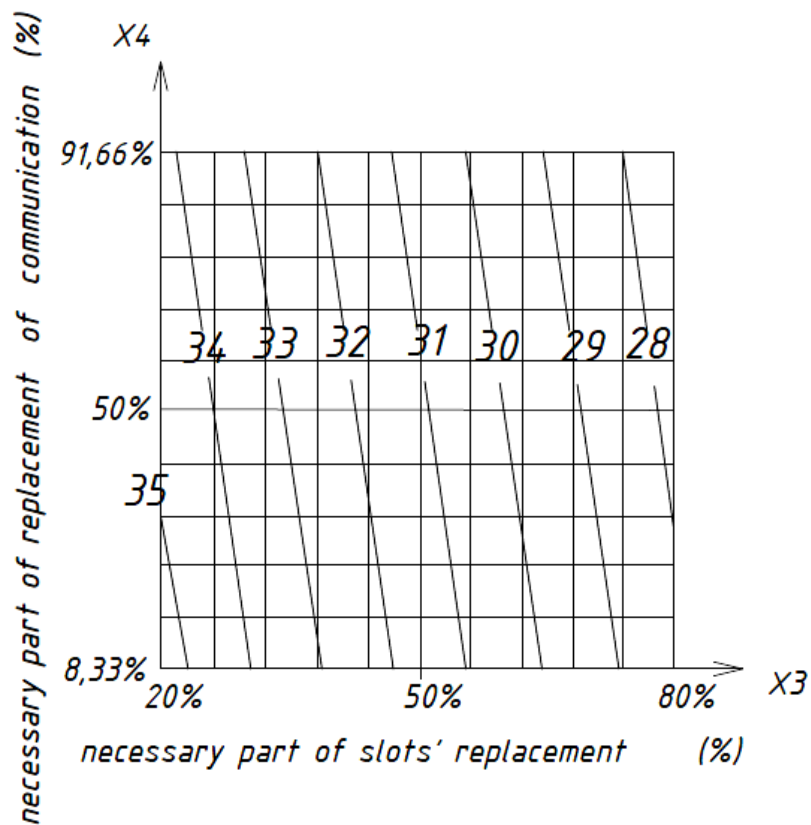

Figure 2 - 2-factor chart of factors impact $\left(X_{3}, X_{4}\right)$ on reconstruction profitability $\left(Y_{3}\right)$ without habitants' eviction 
Change of index of reconstruction profitability $\left(Y_{3}\right)$ is presented in the form of contour lines with interval $1 \%$. Maximum value of reconstruction profitability index is $+35.371 \%$, and minimum $+27.301 \%$.

Edge of reconstruction profitability index efficiency has been adopted on the basis. By reconstruction on investments by the state this index is $8 \%$ and more.

In the given study the boundary permissible index of dwelling reconstruction is $Y_{3} \geq 8 \%$. Such proportion of profitability enables to execute works with getting profit.

As one can see from Figure 2 reconstruction without habitants' eviction is profitable by any combinations of factors' values and is more than $8 \%$.
Superposition of restriction of profitability index $Y_{3} \geq 8 \%$ by reconstruction with habitants' eviction on charts of impact of factors $X_{1}$ and $X_{2}$ (Figure 3) illustrates that by any combination of factors reconstruction is unprofitable because there is an area of acceptable solutions in every chart. It can be reached the maximum indexes $\left(Y_{3}\right)$ of reconstruction profitability by combination of factors $X_{1}$ from -1 to 0 (from 40 to 76 working hours per week ), by $X_{2}$ from -1 to 0 (coefficient of works' overlapping from 0,15 to 0,25$)$, by $X_{3}$ from -1 to 0 (necessary part of slots' replacement from $20 \%$ to $50 \%$ ) and by $X_{4}$ from -1 to +1 (necessary part of communications' replacement $91.66 \%$ ).

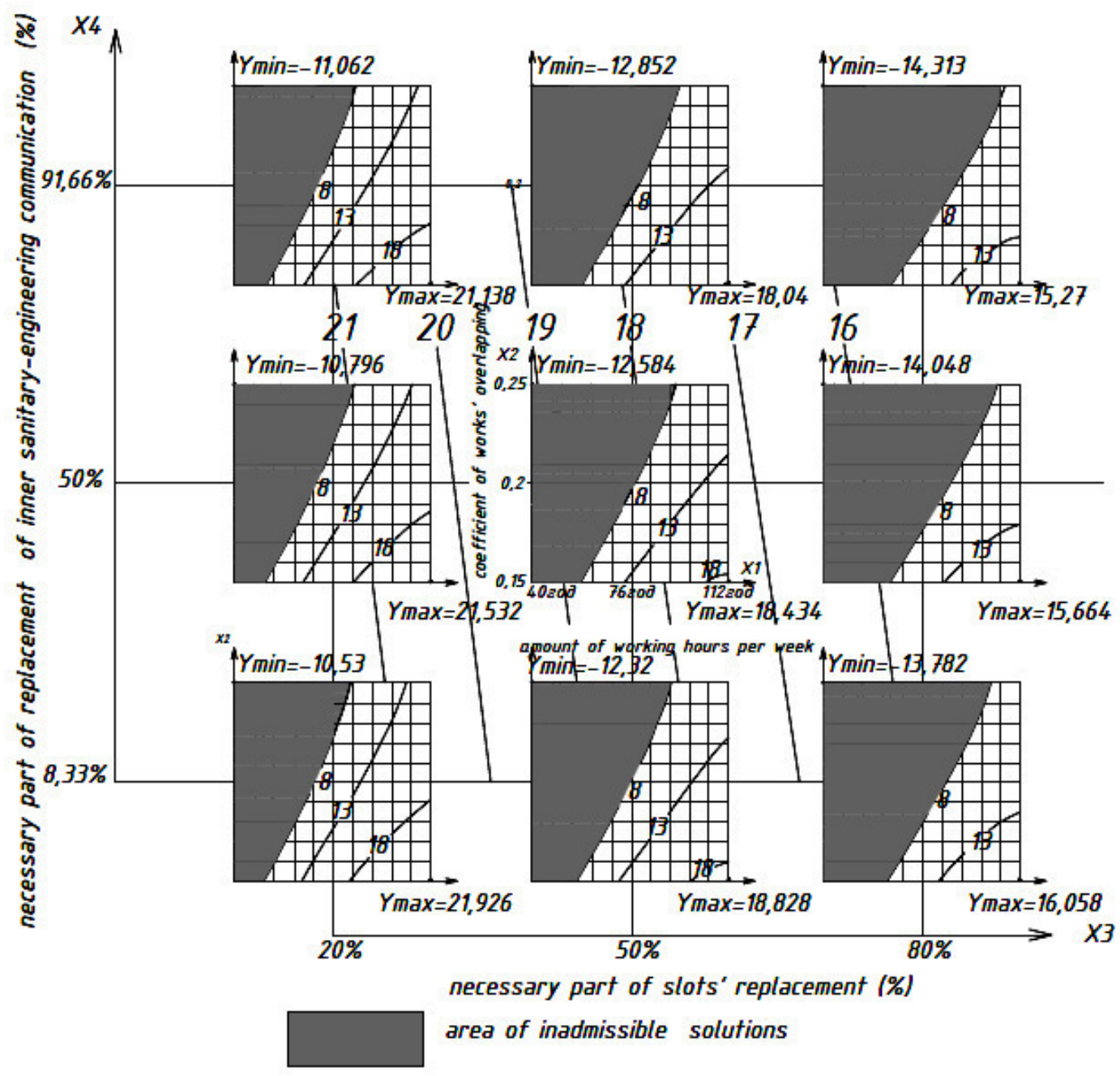

Figure 3 - The chart "square by square" illustrates the restriction of reconstruction profitability $Y_{3} \geq 8 \%$ by the condition of habitants' eviction

\section{Conclusions}

The dependencies between organizational and technological factors and indexes of reconstruction profitability have been obtained for the first time on the basis of experimental and statistical modeling.

The analysis of graphical image of profitability dependency on factors has illustrated that reconstruction by habitants' living in the house during the works execution exceeds the index of lucrative profitability in 3 times. By reconstruction with habitants' eviction during works' execution the areas of effective solutions have been defined. The results of the study illustrated that dwellings reconstruction is profitable. The methodology of the study can be used for the study of other indexes of dwellings reconstruction of first mass series. 


\section{References}

1. Об'ємно-планувальні принципи і методи реновації масової житлової і громадської забудови. (2016). Молодий вчений, 1(28). Взято з:

http://molodyvcheny.in.ua

2. Державна служба статистики України: офіційний веб-сайт. (2018). Статистичний збірник «Регіони України» 2018. Взято з:

http://www.ukrstat.gov.ua

3. Бойко, М.Д. (1993). Техническое обслуживание и ремонт зданий и сооружений. Справочное пособие. Москва: Стройиздат.

4. Куркин, Н.П., Волошко, М.С., Неверов, А.Г., Щукин, С.В., Розенфельд, М.С., Родыгина, М.М., Куркин, А.Н., Вольская Р.И. (2012). Диагностика технического состояния жилых зданий. Луганск: Янтарь.

5. Серии домов и планировки. Серии домов Украина (2012). Взято з:

https://tipdoma.com/serii-domov-ukraina/

6. Māju pārbūves iespējas. (2012). Взято 3:

http://www.parplanosana.lv

7. Архітектурне бюро Stefan Forster Architekten. Взято 3:

https://www.sfa.de/home

8. Stefan Forster architekten GmbH. Взято 3:

https://www.baunetz-architekten.de

9. Джохадзе Натия. (2014). Программа комплексной реабилитации жилых домов массовой застройки первого поколения (на примере г. Тбилиси). Heinrich-Böll-Stiftung. Взято 3: https://ge.boell.org

10. Комплекс градостроительной политики и строительства города Москвы. Какие серии домов подлежат сносу в Москве. Взято 3: https://spbnovo.ru

11. Paz, J. C., Rozenboim, D., Cuadros, Á., Cano, S. and Escobar, J. W. 2018. A Simulation-Based Scheduling Methodology for Construction Projects Considering the Potential Impacts of Delay Risks. Construction Economics and Building, 18:2, 41-69.

http://dx.doi.org/10.5130/AJCEB.v18i2.5842

12. Amin, K.F. \& Abanda, F.H. (2019). Building Information Modelling Plan of Work for Managing Construction Projects in Egypt. Journal of Construction in Developing Countries, 24(2). 23-61.

https://doi.org/10.21315/jcdc2019.24.2.2

13. Chamulova, B. (2011). Increasing time scheduling efficiency in the building process. Slovak journal of civil engineering, 2, 16-20
1. Volumetric and planning principles and methods of renovation of mass dwelling and public buildings. (2016). Young scientist, 1(28). Retrieved from:

http://molodyvcheny.in.ua

2. Public service of Ukrainian statistics official website(2018). Statistical collection «Regions of Ukraine» 2018. Retrieved from:

http://www.ukrstat.gov.ua

3. Boiko, M.D. (1993). Technical maintenance and repair of the buildings and constructions Reference book. Moscow: Stroyizdat.

4. Kurkin, A.P., Voloshko, M.S., Neverov, A.H., Shchukin S.V., Rozenfeld, M.S., Rodyhina, M.M., Kurkin, A.N., Volskaya, R.I. (2012). Diagnostics of technical conditions of dwellings. Luhansk: Yantar

5. Series of houses and planning. Series of houses of Ukraine. (2012). Retrieved from:

https://tipdoma.com/serii-domov-ukraina/

6. Māju pārbūves iespējas. (2012). Retrieved from:

http://www.parplanosana.lv

7. Engineering office Stefan Forster Architect. Retrieved from:

https://www.sfa.de/home

8. Stefan Forster architekten $\mathrm{GmbH}$. Retrieved from:

https://www.baunetz-architekten.de

9. Dzhokhadze Natiya. (2014). The program of complex rehabilitation of the dwellings of mass housing development of first generation (by example of Tbilitsi). Heinrich-BöllStiftung. Retrieved from: https://ge.boell.org

10. Complex of town planning policy and building of Moscow. What series of houses are to be demolished. Retrieved from: https://spbnovo.ru

11. Paz, J. C., Rozenboim, D., Cuadros, Á., Cano, S. and Escobar, J. W. 2018. A Simulation-Based Scheduling Methodology for Construction Projects Considering the Potential Impacts of Delay Risks. Construction Economics and Building, 18:2, 41-69.

http://dx.doi.org/10.5130/AJCEB.v18i2.5842

12. Amin, K.F. \& Abanda, F.H. (2019). Building Information Modelling Plan of Work for Managing Construction Projects in Egypt. Journal of Construction in Developing Countries, 24(2). 23-61.

https://doi.org/10.21315/jedc2019.24.2.2

13. Chamulova, B. (2011). Increasing time scheduling efficiency in the building process. Slovak journal of civil engineering, 2, 16-20 